\title{
Jumping into Faith: The Phenomenon of Brazilian Pentecostal Conversions
}

\author{
Renata Siuda-Ambroziak (D) https://orcid.org/0000-0002-6594-0058 \\ Research Group on Latin America and the Caribbean (CESLA) \\ Institute of the Americas and Europe \\ University of Warsaw \\ CAPES - Brazil, Federal University of Santa Catarina \\ r.siuda@uw.edu.pl
}

\begin{abstract}
In the article, the author focuses on the phenomenon of Pentecostal expansion among contemporary Brazilians, first discussing some sociocultural contexts of massive conversions by means of applying chosen theories to the Brazilian religious context, and then looking at the decisions behind religious transitions through their socially and culturally situated perspective, which prepares a relevant background for understanding the reasons and meanings of individual decisions dealt with in the second part of the article. Based on conversion "flashes" from individual testimonies given by converts, the author makes an attempt to show the common and most enticing features of Pentecostal conversion in a search for an explanation for its "snowball effect" in Brazil.
\end{abstract}

Keywords: Pentecostalism, Brazil, conversions

Słowa kluczowe: pentekostalizm, Brazylia, konwersje

\section{From the fieldwork diary}

While riding a bike along one of the streets of my borough in Florianópolis on the first Sunday afternoon, I start counting churches that I am passing by in the closest neighbourhood. Almost all are Pentecostal (or Neo-Pentecostal). ${ }^{1}$ There are eight of them altogether. The closest

${ }^{1}$ Despite the widespread accord among scholars regarding the rapid growth of Pentecostalism in Latin America, there is no general agreement on how to precisely define this religious movement, as the term covers a great variety of Holy Spirit-oriented forms of Christianity, including charismatic and revival movements. Sometimes the term "Pentecostalism" is used in Latin America to define practically all denominations that emphasize all possible "manifestations of the Spirit." For the sake of this study, 
Catholic church, at least five kilometres away, a beautiful, old chapel on the dunes, provides services only on Saturday evening - due to the lack of priests and the great territorial extent of the parish. I first leave the bike in front of the Assembléia de Deus. The building is very well maintained; there is an air-conditioning system inside, which allows a nice rest from the heat and humidity outside. Almost all the seats have already been taken. People are wearing elegant clothes, men mostly shirts and some of them ties, women - dresses and some of them high heels. The faithful seem to be mostly European descendants, though some of them have darker shades of skin. In the last two decades, the city has received an enormous influx of migrants: from abroad (Argentina, Uruguay) and from other regions of Brazil, mostly from São Paulo and Porto Alegre. One easily notices these demographic changes here as well - some of those present speak "Portuñol," a local mixture of Portuguese and Spanish. Some others have a strong "paulista" (inhabitants of São Paulo) or "gaúcho" accent (people from Rio Grande do Sul), very distinct from local "manézinho" speech. It seems to be an "aspiring lower-middle class" congregation, coming to church in their own cars, with kids, who during the service stay upstairs in a closed room under the supervision of young female church volunteers.

The hall is quite big; around hundred people could sit there comfortably. On the stage in front there is a pulpit, behind it a white curtain draped on the wall. On the left, there are modern instruments prepared for the musicians and worship team. There are some elegant posters on the wall with Biblical quotations. The service begins with a long session of music and singing it goes on for about an hour. The congregation visibly enjoys this part; they join in, raise their hands, and most of them stand in front of their chairs, and move to the rhythm of the music. Then comes the moment of prayer: silent or loud. Later it is time for the pastor to minister the service. It takes another hour. His words are self-confident. Sometimes he gets really emotional and then his voice turns hoarse and forceful. Now and then, the congregation responds, readily, passionately and loudly...

Later the pastor asks the members to come forward one by one, prays for those who approach him, makes the sign of the cross on their foreheads, and lays his hands on them. Two young people come out to give their testimonies of conversion. They speak for about thirty

I see Pentecostalism as an internally diversified religious movement of conversion, with Protestant roots, concerned primarily with the experience and practice of the Holy Spirit's gifts. Classical Pentecostalism originated in Los Angeles in 1906 at 312 Azusa Street, where racial issues were confronted together with class segregation by means of an outpouring of the Holy Spirit and grace, resulting in Durkheimian effervescence - cf. H. Cox, Fire from Heaven: The Rise of Pentecostal Spirituality and the Reshaping of Religion in the Twenty-First Century, Reading, MA 1995. This event ended in miracles, countless conversions, and "boundary breaking" in a society marked by racism and segregation (W.J. Hollenweger, The Black Roots of Pentecostalism, [in:] Pentecostals after a Century: Global Perspectives on a Movement in Transition, A. Anderson, W.J. Hollenweger (eds.), Sheffield 1999; W. César, From Babel to Pentecost: A Social-Historical-Theological Study of the Growth of Pentecostalism, [in:] Between Babel and Pentecost: Transnational Pentecostalism in Africa and Latin America, A. Corten, R. Marshall-Fratani (eds.), London 2001); prophesy (glossolalia), divine healings and supernatural experiences together with a strong religious revival and mass conversions (D. Stoll, Is Latin America Turning Protestant? The Politics of Evangelical Growth, Berkeley-Los Angeles 1990; C.M. Jr. Robeck, The Azusa Street Mission and Revival: The Birth of the Global Pentecostal Movement, Nashville, TN 2006; D. Dayton, Theological Roots of Pentecostalism, Peabody, MA 2000; A.H. Anderson, Spreading Fires: The Missionary Nature of Early Pentecostalism, London 2007). The most recent trend in Brazilian Pentecostalism, which is not of interest to us here, makes use of the media and modern technologies in evangelizing, and preaches the so-called "prosperity gospel" or "health and wealth gospel," evolved from North American televangelism, and is usually described as the Neo-Pentecostal movement, specific to large urban communities, stressing the importance of exorcisms and miraculous healings. The most important representative of Brazilian Neo-Pentecostalism is the IURD - Igreja Universal do Reino de Deus (Universal Church of the Kingdom of God), cf. R. Siuda-Ambroziak, Religia w Brazylii. Uwarunkowania społeczno-kulturowe, Kraków 2015. 
minutes. Then they are formally accepted into the community by the pastor. The service ends in a nice, calm atmosphere. People mingle for a while before collecting their offspring from upstairs and leaving.

Later, I go to a small Pentecostal church - "Adoração a Deus." It is different. The church is in a small barrack painted white. The pastor is an elderly man, sitting behind the pulpit on the stage. He actually seems to be having a short nap. His wife is outside, inviting people to attend the service. I go inside. The barrack could house no more than thirty-forty people, but there are still quite a lot of places left. Instead of air-conditioning, there are two plastic fans on the ceiling. The majority of those present are women, decisively darker than in the previous church, some of them with clearly African or Indigenous features. They are also wearing their best clothes, but one can see that they have a completely different social background. They are accompanied by small children, who sit quietly on white, plastic chairs, listening to one of them singing loudly. With the exception of the pastor, there is only one more man present - a guitarist.

After the singing introduction, where everybody actually does whatever they feel like doing (some sing, some others dance, some clap their hands, some others pray), also lasting for about an hour, the pastor opens his eyes, stands up, comes up to the pulpit and begins preaching. He prays in a strong, emotional voice. He speaks with the Bible in his hand, talking about how to fight against Satan and the evils of the world. Now and then he asks the congregation for an "Amén." Then, some of the members stand up at the front for intercession - the pastor prays for them individually, lays his hands on them. Some of the women get really emotional, I can see and hear some of them shouting, crying. Suddenly one of the women starts "speaking in tongues" and the congregation listens in awe...

I come back home quite late, after dark. To the despair of my neighbours, who consider it at least risky, if not totally "out of place" - after all, they explain, I am a "gringo." When they see me, sighing visibly with relief, we start talking about the past day - I tell them about the churches I visited. When they find out about my interest in Pentecostalism, soon they start telling me, to my amazement, their own stories of their own conversion and how it has miraculously changed their lives... the words that appear most often are: overwhelming, amazing, fantastic, love, preaching, testimony, decision, give your life to Jesus, prayer, sense of peace with yourself and the world, forever. There are emotions, gestures and lots of tears when they tell me about how they were "saved" and "born again." How they found God. And how He cured them and saved their family. They are migrants from Curitiba, one of the cities in Brazil with the biggest population of Polish descendants. Actually, after three hours we come to the conclusion together that her maiden name is definitely also Polish, though she was always sure it was Ukrainian...

In my bed, at around 4 A.M., I keep thinking how Pentecostalism is not only extremely diversified, but also still evolving, how Brazilians are "religiously enchanted," how "conversion" seems to be the core phenomenon in the Pentecostal expansion. Conversion as experience, conversion as a process, conversion as "being born again," conversion as sanctification, conversion as cleansing, as purging, as making holy... I'm also thinking about how Pentecostalism seems to be stratified in the Brazilian social environment. Has it really, as Hollenweger predicted, "come to a crossroads," where it can either go towards the middle-class members or come back to its primary social roots? ${ }^{2}$ Not necessarily. The movement has grown so much that it can appeal to many strata of Brazilian society, using various means for expanding its influences. I lean more towards what Cox once explained: "Indeed Pentecostalism's phenomenal power to embrace and transform almost everything it meets in the cultures to which it travels is one of the qualities that gives it such a remarkable energy and creativity." "It seems to me that because of its flexibility, it is a wave that can be neither controlled nor stopped. A real religious tsunami. In other words - a fantastic research adventure...

\footnotetext{
${ }^{2}$ W.J. Hollenweger, op. cit., p. 33.

${ }^{3}$ H. Cox, Fire from Heaven..., op. cit., p. 147.
} 


\section{Introduction}

The contemporary religious market in Brazil incorporates many competing faiths and religious organisations, the majority of which, roughly speaking, fall into two Christian groups. This makes Brazil at the same time the most Catholic country in the world, in spite of the recent sharp decrease of the Catholic population (1970-91.8\%; $1980-89 \% ; 1991-83 \% ; 2000-73.6 \% ; 2010-64.6 \%$ ), and the most Pentecostal in the world, with Pentecostalism systematically growing (1970 - 5.2\%; $1980-6.6 \%$; $1991-9 \% ; 2000-15.4 \% ; 2010-22.2 \%) .{ }^{4}$ The first Pentecostal movement appeared in Brazil in 1910, brought from the United States by two Swedes, Daniel Berg and Gunnar Vingren, who, while baptised in the Holy Spirit in the Chicago Pentecostal community, were ordered to go on an evangelical mission to Brazil. The missionary zeal to spread the Pentecostal fire of revival proved to be strong enough to form a religious movement, in which the global and the local were, right from the beginning, tightly interconnected - Brazilian society quickly absorbed and "domesticated" Pentecostalism, endowing it with specific Brazilian cultural features. What definitely helped was the intenseness of Pentecostal religious experiences, as well as singing, dancing, trance, vision, healing, speaking with the language of the heart, expressing the incomprehensible, passing on orally conveyed, strong messages, and the telling and re-telling of conversion stories. All these important Pentecostal "ingredients" have become very attractive to Brazilians, mostly to those of African origins, slave descendants, who were also responsible for its North-American origins. The Assembléias de Deus (Assemblies of God), the first Pentecostal communities in Brazil, are the largest Pentecostal movement there and, what's important, still growing; with the exception of the forced conversions of African slaves and Indigenous peoples to Christianity in the colonial period, there have never been more massive transitions in religions in Brazil than in the last four decades (since the 80s), during which more people have converted ${ }^{5}$ to Pentecostalism than at any previous time in history. Even

${ }^{4}$ According to the 2010 National Census data on religious affiliation by the IBGE (Brazilian Institute of Geography and Statistics: www.ibge.gov.br), cf. statistical analysis of the Census data: R. Siuda-Ambroziak, Brazylijski rynek religijny na poczatku XXI wieku (na podstawie danych ze spisu powszechnego IBGE z roku 2010), "Ameryka Łacińska” 2013, vol. XIX, no. 1 (79), pp. 99-106; eadem, As mudanças e transformações recentes do mercado religioso brasileiro, "Iberoamericana Quinqueeclesiensis" 2016, vol. XIV, pp. 15-23.

${ }^{5}$ I understand the term conversion as an event (or a process) of religious transition; in the Pentecostal context, it is usually marked by strong and overwhelming spiritual experiences, causing a dramatic personal and spiritual re-orientation (S. Cucchiari, "Adapted for Heaven": Conversion and Culture in Western Sicily, "American Ethnologist” 1998, no. 15 (1), pp. 417-441; H. Cox, Fire from Heaven..., op. cit.). Within Christianity there are different understandings of "conversion" - in the Catholic Church the conversion process is believed to take place through participation in the sacraments of baptism, Eucharist and the First Communion, while Pentecostal churches believe that conversion is a personal experience that happens when someone is baptised in the Holy Spirit (M.D. Bryant, C. Lamb, Introduction. Conversion: Contours of Controversy and Commitment in a Plural World, [in:] Religious Conversion. Contemporary Practices and Controversies, M.D. Bryant, C. Lamb (eds.), London-New York 1999, p. 18). The conversion phenomenon is central to the Pentecostal context, constituting the very core of the movement and its key symbol. Within Pentecostalism, being "born again" is contrasted with "nominal" Christianity, based 
though these numbers include generations already born into converted families, there are still new, apparently massive, adult Pentecostal conversions, which constitute extremely interesting issues for scientific analysis. Why do Brazilians so often choose Pentecostal conversion as their religious "life strategy"? Is it just an internal pressure in search of the sacrum, or does there exist a strong outside, profane pressure for them to adapt in such a spiritual way to the changing sociocultural environment? Massive conversions might constitute, apart from always being the sum of individual experiences, important sociocultural processes and phenomena, often only mere symptoms of bigger and much more serious changes and transformations going on in a given society. Furthermore, they may sometimes point to deficiencies in the system and the feeling of impotence and vulnerability in dealing with them - triggering the need for changes, and opening the door, at least potentially, to a religious transformation or adaptation.

However, analysis of religious choices is always very difficult. This is especially so in such a context (as described in this paper) where there are sudden outbursts of emotions and a close contact with the supernatural - here theoretical and methodological discipline often fail. We simply lack the scientific tools for explaining many events and processes of a religious character, only hinting at them, and deducing. Conversion is one of them - an extremely complicated phenomenon, that is at the same time sociocultural and individual. Sometimes rough and painful. But always exceptional, showing meaningful correspondence between the sacred and the profane, the individual and the social, mirroring each other.

In order to better understand the phenomenon of Pentecostal expansion among Brazilians, I start by discussing some sociocultural contexts of massive conversions on the basis of applying chosen theories to the Brazilian religious context. Next, I look at the decisions behind religious transitions (seen here as conversions of groups) from the perspective of their socially and culturally situated context, which provides, I assume, a relevant background for understanding the reasons and meanings of individual decisions. I obviously choose to emphasize certain theories, while only mentioning others in passing, and excluding many others completely. The choices I make are grounded in my Brazilian religious studies experience, as well as field research carried out in Brazil, in Florianópolis in December 2017, ${ }^{6}$ some empirical results of which are presented in the second part of the article. There, I show a few conversion "flashes" from individual testimonies given publicly by converts in front of their respective congregations, and excerpts from interviews conducted with ten adults - Pentecostal faithful - living in the neighbourhood, attending two different churches in the same borough. In this way, I attempt to show (in spite of all the obvious structural and social differences between the two congregations, as well as the fact that it is difficult to treat Pentecostalism as a homogeneous movement),

on tradition rather than actual experience of faith and a direct relationship with God lived through the outpouring of the Holy Spirit.

${ }^{6}$ The research was done at the beginning of my annual CAPES-Brazil scholarship (visiting professor and senior researcher) at the Federal University of Santa Catarina in Florianópolis (December 2017December 2018). 
the common, and most enticing features of Pentecostalism in the eyes of its "beholders" in search of an explanation for its "snowball effect" expansion. In this part, I employ a phenomenological approach, believing that, although specific social, and cultural (and sometimes even political and economic) aspects discussed in the first part are intrinsic to the analysis of the phenomenon, and, obviously, we can and even should look at Pentecostalism as a form of revitalizing, collective movement, the most important point is always the undergone, personal experience of conversion of the individuals recounted by the informants in their narratives, as well as the impact it has on their lives. I focus here on the conversion phenomenon, its descriptions and consequences, as provided by the converts themselves, who present it as an extremely desirable and enticing "event" or "process." Such a focus, I hope, will help me show the essential role that the Pentecostal conversion itself - as an individual and social phenomenon, completely changing the life and often identity of the converts, but also of their families and environment - may play in the expansion of the movement. I support the significance of the conversion in the Pentecostal expansion by showing the specific cultural demands of the faithful, fostered by an important African ingredient of Brazilian Christianity, and a strong charismatic religious leadership, providing safety and precise rules of conduct in a Brazilian society that is heavily divided and suffering from recurring crises. I emphasize, therefore - by looking at theoretical approaches and individual stories of conversion - the role of both social and cultural, individual and communitarian, global and local contexts of Pentecostal movement expansion in Brazil as important backgrounds in which (or, due to which) Brazilians keep converting and choosing Pentecostalism among so many available religious alternatives.

\section{The sociocultural context of Pentecostal conversions in Brazil}

The history of science reveals an uneven line of development, with the paths taken reflecting successful problem-solving, but also generating new issues and research problems, which pile up until the existing theories and concepts are transformed, revitalized or totally abandoned. The adequacy of a scientific explanation is always related to the maturity and state of development of its underlying theory. Such a theory can be improved by means of research, which, even if it focuses on the original problem (which gave rise to the theory), often reveals previously ignored reciprocal effects and influences of many factors. Assuming the integration of different theoretical approaches in order to obtain a more complete picture of the studied phenomenon, I will attempt to select and apply to the Brazilian situation those theories which could at least partly indicate and explain Pentecostal conversions in the contemporary Brazilian religious market. Theoretical pluralism - reflecting openness to the multiplicity of different scientific explanations ${ }^{7}$ - as rightly observed by Craig Calhoun, means noting the dialogue between multiple disciplines and their theories relating to

7 J. Beckford, Teoria społeczna a religia, transl. M. Kunz, T. Kunz, Kraków 2006, p. 37. 
the research problem. Each theory offers a certain aspect of truth, yet none is, unfortunately, perfectly satisfying. ${ }^{8}$ The religious phenomena and their social background have always been of interest to scholars, independent of their discipline or theoretical approach. There have been those who regard religion as an ideology, treating it as a concealment of basic social conflicts, and others who have looked at it as a kind of social cement, unifying society, or have seen in religion the source of collective representations organizing a society, its life and functioning. Furthermore, there have also been scholars treating religion as a necessary force to guarantee the continuity of social groups and guide interactions among their members. And, finally, there have been those who understand systems of beliefs as symbols through which each society (and each individual) represents the central themes of their worldview, making relevant affirmations about the way in which social (and individual) life is organized. All these presumptions and perspectives might be helpful to better understand religious contexts in a given society and in the life of a particular individual in a determined social group, especially if looking at the notions, values and interests that guide them in making decisions and choosing between various religious options.

When starting to interpret any contemporary religious phenomena, including conversions, especially massive ones, we cannot avoid "bumping into" the theory of secularization - controversial on the one hand, yet a key to any further investigation on the other. According to its original assumptions, religion, at least in its institutional forms, was doomed to marginalization and fading as a factor hindering the possibility for the development of modern societies that solved problems on the grounds of scientific cognition, a search for the truth, and rational discourse based on evidence. Numerous studies showed an inevitable decrease in the importance of religion, which was regarded as "collective neurosis," "opium for the people," the "twilight of the gods," "disenchantment with the world," or "the death of God." Even a few decades ago, in the $60 \mathrm{~s}$ and $70 \mathrm{~s}$, many scholars confirmed that the process of secularization would soon make religion an outdated phenomenon in post-modern conditions. ${ }^{9}$

Nevertheless, at the same time, some researchers started looking for possible new functions, "places" and types of religion, reflecting their views in numerous theories. At the end of the twentieth century, even some earlier "religion-sceptical" scholars admitted not having dealt in their secularization diatribe with "the extensive evangelical renaissance of Christianity," excluding it, as an exception to the rule, from their analysis..$^{10}$ But it was precisely the growth of Pentecostalism that forced many scholars to re-think their position on secularization processes colliding so painfully with regard to the empirical context under study. The Pentecostal movement, especially in the Latin American context, ran counter to the statistics indicating secularization trends, identifying itself as a powerful, grassroots, "reactionary" movement,

${ }^{8}$ C. Calhoun, The Social Theory and The Public Sphere, [in:] The Blackwell Companion to Social Theory, B. Turner (ed.), Oxford 1995, pp. 429-470, 435.

${ }^{9}$ H. Cox, The Secular City, London 1965; D. Martin, A General Theory of Secularization, Oxford 1978; P. Heelas, Introduction: On Differentiation and Dedifferentiation, [in:] Religion, Modernity and Postmodernity, P. Heelas, D. Martin, P. Morris (eds.), Oxford, MA 1998.

10 D. Martin, A General Theory..., op. cit., p. 13. 
distancing itself from stagnated and institutionalised religious institutions, wanting to be "a genuine living church," cially regarding family and social relations, religion still has an important potential. The research on Pentecostalism took off then, becoming more extensive and addressing various dimensions of the movement, as well as looking for the reasons for its expansion and its potential to transform both individuals and whole societies. Martin repeatedly confirmed that Pentecostalism can be an important strategy to manage modernity and leave a "traditional" way of life behind through the unique conversion experience and filling with the Holy Spirit. ${ }^{12}$ Adventurous Pentecostals, especially the strong, charismatic leaders, were the ones to "break the secularization pattern" of Western Christianity and rules of conduct in the religious sphere, placing themselves outside traditional institutionalized religious structures, becoming innovators and predecessors to collective conversions and religious awakenings. In Brazil, Pentecostal communities have mostly developed and grown thanks to the charisma of their local pastors - effective, coming from among the people, deeply passionate, colour-blind, open to everyone, regardless of race and social background, reaching others with simple, understandable language, and "getting to people's hearts," which, as overemotional as it seems, appears to be an important factor in stimulating Pentecostal demand in the Brazilian market. ${ }^{13}$ In spite of its "imported form," Pentecostalism has a lot to do with local cultural continuity - first of all, Pentecostal conversion does not constitute a dramatic change within the majority Christian group, and, secondly, Pentecostalism was introduced to Brazil through important semantic bridges and symbolic equivalences that had to do with the presence of Afro-, and at the same time, slave-descendants both in its country of origin (the United States), and destination (Brazil). Therefore, some of its important ingredients (contact with omnipresent spirits, trances and possessions, oral narrative dynamics, "religious joy" with emotions, music, gesture, healings, and miracles, and an initial involvement in a movement with no race, class, or age distinctions) were adopted directly in Brazil and instantly regarded as "local." The same happened with regard to the pastor's position of power, which was not viewed as something negative - on the contrary, it was expected and considered healthy. Pastors are the "shepherds of the herd," with authority to discipline and reprimand, but also encourage and praise - extremely important, powerful agents of Pentecostal proselytizing success in Brazil, very efficient in "fishing" for new souls, applying the perspective of moral superiority, and restoring in their believers a sense of worth and confidence in their own righteousness ("empowerment").

But, at the same time, Pentecostal churches are far from being social "revolutionary agencies." And that is in spite of the fact that the transformation of self through conversion is emphasized just as is the transformation of the world through prayer and social involvement, which are seen as natural consequences of the conversion experience. The ascent of Pentecostalism was somehow facilitated by the revolutionary

\footnotetext{
11 N. Bloch-Hoell, The Pentecostal Movement, London 1964, p. 12.

12 D. Martin, Pentecostalism: The World Their Parish, Oxford-Malden, MA 2002.

${ }^{13}$ Idem, Tongues on Fire: The Explosion of Protestantism in Latin America, Oxford 1993, p. 108.
} 
attitude of the Catholic liberation theology in Brazil in the 70s and 80s. In those turbulent times, Pentecostals focused rather on healing and individual transformation of the faithful, with their socio-political critique articulated comparatively "safely," and not resulting - unlike in the case of Catholicism - in any open action. ${ }^{14}$ The driving force of the Pentecostals has always been rather to spread "God's order" to a morally and spiritually corrupt society than to directly proclaim any social or political revolution, although it is not fruitful to make a clear demarcation between religion and politics, as these two spheres are indeed blurred in Brazil, with many examples of Pentecostal (mostly Neo-Pentecostal) churches becoming important political powers. ${ }^{15}$ Traditional Pentecostalism is, above all, a religion that is oriented towards local, individual and family quality of life, with a belief in miraculous healings, personality change, abstention from alcohol and drugs, and the importance of family strength and loyalty. In conjunction with a very strong commitment by adherents, these factors have a positive impact not only in terms of subjectively perceived "happiness," but also by reducing tension, and cutting down on the level of deviations. ${ }^{16}$ Thus, some scholars started viewing Pentecostal conversion as an experience that empowers the individual, a creative process that leads to "a transformation of the self, marked by new awareness, new social being, and a new relationship of the sacred." ${ }^{\prime 17}$ The conversion experience, the core of Pentecostalism, even creates a new, common language among Pentecostal believers through giving personal narratives and testimonies, which are all about the power and authority of those who know "the Word" and publicly pronounce it. ${ }^{18}$ In the course of my fieldwork, many interviewees mentioned that before Pentecostal conversion they were "insecure," "shy," "inhibited," and "hating public appearances," but with the study of the Bible they acquired all the necessary lexical richness and verbal ability - particularly in relation to specific, Pentecostal religious discourse. Hefner suggested that Pentecostal conversion implies the acceptance of a new self-definition, a new reference point for one's identity. Pentecostal churches constitute a space in which the members seem to forge such a new self. ${ }^{19}$ Similarly, Cox and Martin argue that there is a genuine cultural force in

14 J. Casanova, Religie publiczne w nowoczesnym świecie, transl. T. Kunz, Kraków 2005; R. Siuda-Ambroziak, Religia w Brazylii..., op. cit.

${ }^{15}$ H. Cox, Fire from Heaven..., op. cit.; R. Siuda-Ambroziak, Religião e estado no Brasil contemporâneo: os processos da "(neo)pentecostalização" da política brasileira, [in:] Religión y política en América Latina, K. Krzywicka, R. Siuda-Ambroziak (eds.), "Estudios Latinoamericanos de la UMCS" 2017, vol. V, pp. 109-136.

${ }^{16}$ Hall claims that regular participation in communal religious life is usually positively correlated with a sense of "being happy." Religion also has an impact on the level of social deviation: young people involved in religious life are more likely to graduate and pursue further education, commit fewer offences and are less inclined to use alcohol and drugs (D. Hall, Religious Attendance: More Cost-Effective than Lipitor?, "Journal of the American Board of Family Medicine" 2006, no. 19, pp. 130-139; E.J. Dionne, J. Dilulio, What's God Got To Do with the American Experiment?, Washington D.C. 2000, p. 183).

${ }^{17}$ S. Cucchiari, "Adapted for Heaven": Conversion..., op. cit., p. 417.

${ }_{18}$ Between Babel and Pentecost. Transnational Pentecostalism in Africa and Latin America, A. Corten, R. Marshall-Fratani (eds.), London 2001.

19 R.W. Hefner, Introduction, [in:] Conversion to Christianity, R.W. Hefner (ed.), Berkeley, Los Angeles-Oxford 1993. 
Pentecostalism that has the real potential to transform individuals and societies. ${ }^{20}$ Brusco argues that Pentecostal conversion has the power to transform gender roles in families through a process which she calls "the domestication of men," showing that the conversion of men results in a better family situation, with the men investing money in the household rather than wasting it on drinking and gambling. ${ }^{21}$ She argues that the new moral conduct every convert is expected to adopt after joining a congregation results in a changed gender order among the members. Pentecostal converts are also "helped out" by their brethren, becoming dependent on fellow members of their congregations when in need, and fully benefiting from the extraordinary transformations going on in their personal lives. Indeed, members of local Pentecostal churches constitute internal networks of relations through which resources of all kinds flow: this was confirmed by many informants, who readily participate in helping "brothers" out of difficult situations, but do not take part in any other local, regional or national charity actions nor support any NGOs - it is clear that the social involvement of the Pentecostals is about creating a "safe haven," a secure home locally. Their religious leaders seem to be important mediators here, evaluating the needs of particular members and their families and providing adequate solutions (not necessarily in terms of money - help could also come in the form of medical aid, support of an initiative, etc.), flowing from those better off towards needy converts or poorer members of the church. Pentecostal churches therefore play the role of "hubs of resource distribution" for the local circulation of material wealth, but also help, protection, and information. In this way, Pentecostalism fulfils several social functions, such as re-integrating a community, and contributing to the social capital ${ }^{22}$ of the faithful stemming from relationships established and maintained by members of the given "brotherhood." What is important is the establishment of close contacts, especially in Brazilian society, where the possibility of "arranging" various matters is often based on jeitinho brasileiro - making appropriate use of one's connections and informal networks of mutual favours. It is the social capital coming from the circles of "brethren" in faith, co-believers in the same local church, that might be a matter of particular importance in the everyday life of average Brazilian citizens. As shown in research by Putnam, believers and members of any church are usually quicker to rebound after crises, being able to count on, especially in the case of weak state structures, charity and expert aid from both their religious institution and individual members of the congregation. More importantly, they are also likely to help others. ${ }^{23}$ According to Beyer, it is

${ }^{20}$ H. Cox, Fire from Heaven..., op. cit.; D. Martin, Pentecostalism..., op. cit.

${ }^{21}$ E.E. Brusco, The Reformation of Machismo: Evangelical Conversion and Gender in Colombia, Austin 1995.

${ }^{22}$ R. Putnam, Bowling Alone: The Collapse and Revival of American Community, New York 2000 , pp. 65-79, mentions the influence of religion on strengthening social ties and developing social capital, defined as connections among individuals-social networks, and the norms of reciprocity and trustworthiness that arise from them, understood both as a structural (friendship or neighbour networks of ties) and a cultural phenomenon (social norms fostering acting together).

${ }^{23}$ Ibidem. People's engagement in the activities and organisational life of churches or religious communities results in a greater probability of their activity and civic solidarity and participation in political and social life on its various levels (K.Q. Hill, T. Matsubayashi, Church Engagement, Religious Values and Mass-Elite Policy Agenda Agreement in Local Communities, "American Journal of Political 
precisely the practical, secular activity of religious institutions involved in social care that contributes to the preservation and strengthening of the social influence of a given option, which means that the popularity of Pentecostalism may be based on its effective "use" of religion for the needs of a specific market of followers. ${ }^{24}$ This thesis is supported by the intensive engagement of Pentecostal churches in solving problems on a local, grassroots level, and providing their members with a feeling of safety - the basic concept of the theory by Norris and Inglehart, who focus on: the relation between religious revival, level of social development, existence of economic and social inequalities, their degree and origins, and the resulting safety level of individuals and groups. ${ }^{25}$ The authors note that nearly all religions in the world assure that force majeure will watch over believers, and they shall be rewarded for following the given principles and values, or punished for non-compliance with them. Such assumptions significantly lower stress levels and reinforce a sense of safety and community. This means that religious revivals appear always when/where people experience some kind of deprivation, stress, or a direct threat to life or health, with a lack of possibilities to take rational measures in order to change such situations or eliminate their source. Therefore, religious beliefs are perfect mechanisms of adaptation to situations seen as difficult, dangerous and extreme. Norris and Inglehart also note that the degree of engagement in religious practices is not only always higher in poorer countries than in richer ones, but also that it is highest in the most socially and economically divided ones. Since Brazil is still one of the leaders in the category of social polarization, even in the context of strongly differentiated Latin America, it enhances the need for any "protective" religion, especially one that is so well culturally rooted as Pentecostalism. Hence, the phenomenon of the popularity of the transnational but at the same time very local Pentecostal offers in Brazil can be perceived as a response to the social, economic, and political problems, tensions, disparities, and disintegration processes. This would lead us directly to the possibility of applying the cybernetics and systems theory by Bateson to explain Pentecostal conversions. Bateson, who defined "cybernetics" as the comparative study of communication flow in a complex social system, states that the comprehension of a phenomenon is possible only if one studies it in the context of all the completed orbits relevant to it. ${ }^{26}$ Such an approach lets us treat "conversion" not only as an individual process, but also as one that affects individuals, the group and the society as a whole ("communitarian" or "societal"). For decisions on conversion to be considered seriously, current religious options must

Science” 2008, vol. 52, no. 3, pp. 570-584; P. Norris, R. Inglehart, Sacrum i profanum. Religia i polityka na świecie. transl. R. Babińska, Kraków 2006, p. 312. This confirms that membership in religious organisations is positively correlated with indices of civic engagement and group solidarity.

${ }^{24}$ P. Beyer, Religia i globalizacja, transl. T. Kunz, Kraków 2005, p. 143.

${ }_{25}$ P. Norris, R. Inglehart, op. cit.

${ }^{26}$ G. Bateson, A Systems Approach, "International Journal of Psychiatry" 1971, no. 9, pp. 242-244; this theory has been proposed as one of the explanations for current religious transformations in Latin America by J.-A. Alvarsson, R. Siuda-Ambroziak, Religiones e iglesias en la formación de una nueva América Latina a finales del siglo XX y principios del siglo XXI, [in:] América Latina del siglo XXI. Nuevas semblanzas, nuevas estructuras, nuevas identidades, A. Dembicz, A. Elbanowski (eds.), Warszawa 2013, pp. 353-410. 
prove somehow impotent in dealing with "powerlessness" towards deficiencies in the system (be it illness or addiction in the case of an individual, or a heavy cultural, social or economic burden in the case of groups), sometimes becoming more and more acute at the moment preceding conversion. In such a situation, people tend to look for new allies - and the Pentecostal movement is definitely a strong commitment system. It also seems to have a practically infinite ability to adapt to local (and personal) needs and conditions. Important studies of Pentecostal transnationalism showed enhancement of feelings of self-affirmation at the local level together with the constitution of forms, images and ideas at the global level and pride of belonging to "something universal," with no firm 'geographical' anchor. ${ }^{27}$ Therefore, the experience of conversion may reproduce itself, maybe even identically, anywhere in the world, being a universal faith experience, but always perfectly adapted to a given culture and reinterpreted in its local context, constituting an intensely personal and very much communitarian and social phenomenon at the same time. This "glocal" - global and local at the same time - feature of the Pentecostal movement leads us to a better understanding of its flexibility and ease of adaptation, its internal autonomy (the organization and structure of individual congregations varies from case to case, subject to transformations, preserving only the most essential qualities of Pentecostalism - a "tight paradigm" of the movement, which consists of preaching a traditional message of conversion and experience of the Holy Spirit), but also its longing for order, stability, a system of fixed, commonly accepted and followed rules, and a strong leadership, based on giftedness.

This could explain the Pentecostal acceptance of charismatic leaders; in fact, as I have already mentioned, there is a certain longing for an authority of exceptionally charismatic personalities in a Weberian sense, assuming the role of catalysts and stimulators of conversions, attracting and engaging people, interconnecting them within a community, making Pentecostal churches sprout and filling them with crowds of believers. After all, the Brazilian religious market is still dominated by church-oriented, affiliated believers, and there is no tendency to push religion into "invisible," private life - people who believe and publicly express their faith are not an exception or a rare phenomenon in Brazil, especially if they are Pentecostal. However, in spite of all the mentioned, very important, cultural, communitarian and social contexts, including the acceptance of the religious authority of charismatic Pentecostal pastors, the process of conversion has to do mostly with an individual experience, with being "touched by the sacrum," with "total surrender to God" and "standing in front of Him alone." This individual experience is what I focus on in the next part of the article.

27 Between Babel and Pentecost..., op. cit. 


\section{Pentecostal Conversion Experiences}

Fieldwork is always a powerful, ethnographic experience - it is often about relationships, friendship, and intimacy, constituting, according to Amit, one of the foundations of the research process, the core of an anthropological "paradox of a very personal experience in the field [...] and the detached theoretical reflection. ${ }^{28}$ However, in the case of this study, I admit that if one has never had an experience of being "born-again" oneself or "speaking in tongues," it is impossible to understand it fully. What remains is to try to capture and interpret the "emotion sensitive" experiences of others through verbal communication (the converts' narratives and testimonies), and participant observation, trying to make them want to tell you their story and believing in what they tell, knowing well at the same time that a researcher is never actually sure if the informants are saying what they really think and feel and if they are able to describe well what they have actually experienced. The things that help me believe that the information I managed to gather is true are: that I have always been, as a Christian myself, welcomed in Brazilian Pentecostal communities (even though they knew of my role as a researcher), and that I speak the language of my informants fluently, which helps me to notice many nuances. What's more - I have always had the impression that my informants really wanted to share their stories and often felt honoured or flattered by my curiosity and inquisitiveness..$^{29}$ First of all, this is because in the Pentecostal congregations, it is seen as important to take one's private religious experience to a public level and share it with others, by testifying. The importance of narrative and storytelling about one's conversion not only "articulates social relationships," but also has a strong therapeutic value: "recounting one's experiences in the presence of others is a way of reimagining one's situation and regaining mastery over it." ${ }^{\prime 30}$ In Pentecostal congregations, giving testimony on your conversion is treated like "a ritual" and "a self-presentation," ${ }^{11}$ being actually a central element of conversion - "acting out" one's new identity. It is also supposed to strengthen the community, to empower not only the individual, but also the collective.

Some of the informants probably expected me at some point to either join them or at least also have a strong religious experience, a "breakthrough" with the Holy Spirit, which, however, did not happen. Some of them must have been quite disappointed with that, although I think that people who gave me their testimonies did not do it necessarily because I was regarded as an important target for evangelization. In spite of any expectations that my presence might have aroused, I listened

28 V. Amit, Introduction: Constructing the Field, [in:] Constructing the Field. Ethnographic Fieldwork in the Contemporary World, V. Amit (ed.), London-New York 2000; K. Hastrup, Fieldwork among Friends: Ethnographic Exchange within the Northern Civilization, [in:] Anthropology at Home, A. Jackson (ed.), London-New York 1987, p. 99.

${ }^{29}$ All informants wanted me to use their real name, when quoting them. I do so in all longer utterances. When quoting single words or phrases, I chose to do so anonymously. All interviews have been translated into English by myself as closely to their original meaning in Portuguese as was possible.

${ }^{30}$ M. Jackson, Minima Ethnografica, Chicago-London 1998, pp. 12, 23.

31 P. Stromberg, Language and Self-Transformation: A Study of the Christian Conversion Narrative, Cambridge 1993, pp. 3, 63. 
respectfully and attentively to whatever discourse was given, trying to understand the meaning as closely as possible.

The Pentecostal conversion experience, which I have come closer to by means of listening to others' narratives, is something that everybody must go through in order to become a "true believer" - and it does not really matter where you come from, which means that it must happen to both those who convert from other options and those who were born into a Pentecostal family. Its universality is always stressed both by pastors and members of the congregations. Pentecostal conversion usually takes the form of a spontaneous and sudden event, and it results in a sequence of successive experiences with regards to the closest group, for example, the family - it seems that the Pentecostal experience of one of its members leaves no one else unaffected. It is not only "a self-transformation," but also "a transformations of others around," leading to an increased commitment to faith - for the conversion stories presented publicly to be credible, one must really show willingness to change one's life, accept new rules of conduct, and "share the congregations' religious culture." Conversions and their testimonies are about new identity formation, a new construction of the "self." To be recognized as a convert, one cannot keep it to oneself or continue living like before. The leader (pastor) and the congregation must confirm and approve one's conversion. As they say "you simply become different" - the conversion always results in an impact so huge that it leads to a change of direction in one's life, a change in views, which motivates to go further, to "exceed yourself." But it must also fit into frames of Pentecostal "socialization," follow a certain pattern, a certain sequence of events and behaviours. Even though there are some restrictions, most people stress "the feeling of freedom" as members of their church, and the services are always characterised by joy, excitement and a longing for miracles and extraordinary events.

The moment of conversion as "a turning point in one's life" usually comes after times of hardship (unemployment, illness, divorce) or after some "wrongdoing." Although everybody has a different story to tell, it usually follows a certain pattern: an account of pre-conversion times (usually sad, full of problems, desperate unhappiness); the moment of truth - the experience of the sacrum, which comes like a fire, like a wind, or quietly - as a sudden, but peaceful "coming to terms with what God wanted of me" and is described as "being acted upon by God," "being touched by God's grace," or "being struck by the Holy Spirit"; the life afterwards (sometimes with some "backslide stories," when "the devil keeps trying to regain control of one's life," but generally - "joy explosion," "becoming alive," "the carnival of my life"). People after the "breakthrough" change visibly and dramatically: they give up addictions, but also they often give up, at least to some extent, their old companions and friends, focusing instead on the closest family; they start praying a lot and finding real pleasure in doing it, feeling strongly attracted to the church and its community. There appears a need to break with the past, to discard personal restraints and complicated relationships. The relations that are preserved are often maintained with the hope of evangelizing those people in the future.

Some time after the "event," some people feel a "gift" enabling them to speak in tongues - "you suddenly feel some words crowded in your head, and you open your 
mouth to let them go and they go. It is something you do not control. It is something that nobody can pretend to do." "You just cannot handle it without letting it go - the words start pushing each other in your head, it starts aching, or it starts burning like a flame." The experiencing of "Holy Spirit gifts" helps converts' recognition in the community, building their moral, social and symbolic capital, ${ }^{32}$ and status in the congregation. Those who have never experienced such a gift often feel like "worse" members. And "worse Christians."

The experience of conversion is often retold, but rarely interpreted, analysed or explained - usually it is left open, as whatever occurred or however, it was the will of God. Conversion is, in terms of individuals, somehow sudden, but then, surprisingly, it is often spoken about by the informants in terms of "a journey," "becoming more and more," "striving for holiness," "being a part of spiritual warfare," as if it was really a never-ending process, only starting with the actual "being struck by the Holy Spirit," with a "rupture," "leaving your past behind." Conversion seems to connect the past, the present and the future in the life of an individual. It is the "reaching beyond the levels of creed and ceremony, into the core of human religiousness, into what might be called "primal spirituality," "the image of God in every person," "a radically new world age about to dawn." " Pentecostals often talk about coming "from a feeling of insecurity to total safety," "from darkness to light," "from living a life filled with emptiness to living a life full of blessing." In the process preceding conversion, many people "had dreams" or "visions," in which someone told them what to do and where to go:

I had a dream, and then I woke up with an exact picture in my head, a sort of a map, which showed me exactly where to go and whom to speak to. So when I went to the church, there were two pastors there and I could distinctly remember the face of one of them as if we had already met before. I instinctively approached him. And he seemed to know me already. He looked at me as if he knew me well. (Davi, 42, 12.12.2017)

I had a strong feeling, almost a physical compulsion. I knew something would change in my life very soon. It was butterflies in my stomach. It was excitement. And awe. I was getting prepared to be healed. It happened spontaneously. I did not prepare for it. I did not do anything for me to have experienced such grace. Nothing. I felt so happy and chosen. (Antônia, 36, 26.12.2017)

I thought I would be able to experience God just like his first disciples, directly, as if He was holding my hand. Tangibly. Not through the priest or a bishop. I wanted Him to look at me. I wanted to see Him. And it was just as if He was in my room. (Elisa, 27, 23.12.2017)

I come from a Pentecostal family. But I had my own way of reaching my own faith. I was rather sceptical, when going to church with my parents. I protected myself well against God, Holy Spirit, all that nonsense... But on a given day, when I was 23, I just couldn't stand it anymore. God was speaking to me so strongly, so loudly... I started praying and I let it go. I gave my life to God. And I suddenly felt peace in my heart. For the first time in my life. I was totally overwhelmed with His love. (Tony, 29, 07.12.2017)

${ }^{32}$ P. Bourdieu, Social Being, Time and a Sense of Existence, [in:] idem, Pascalian Meditations, Cambridge 2000, p. 241.

${ }^{33}$ H. Cox, Fire from Heaven..., op. cit., pp. 81-82. 
An immediate effect of individual conversion is a feeling of euphoria, freedom and happiness, as if life was actually re-starting:

I felt like, I don't know, as if I entered into a trance. It was some kind of an ecstasy, release of total power that I never knew I had... (Elisa, 25, 09.12.2017)

Sometimes, at the beginning, there is a lack of words to pass on these overwhelming feelings; then there slowly appears a "Pentecostal discourse," in which some words and phrases keep being repeated to describe the life "before" and "after" conversion - it seemed to me, just like Berger and Luckmann stated, that individuals may sometimes tend to "colour" events to harmonize the reinterpretation of the past with the facts of the present: "subjectively seen, he is not telling lies about the past, but brings it in line with the (present) truth that necessarily includes both the present and the past." 34 Several times, when I asked about the past (before the conversion), the teenage years, the beginning of the marriage, the time when the children appeared, it seemed to me that they started talking with pleasure and nostalgia, but suddenly remembered that it was actually supposed to have been "bad":

It was really funny when we met... we used to go to the same school, we had lived on parallel streets for more than twenty years and nothing. And then suddenly it happened. I saw her in that fantastic red skirt and she looked so great, so beautiful to me, she actually was so pretty, that I thought - I must have been blind... You got to know Barbara, she's my wife now, right? When we got married, we weren't what we are now yet. These were fantastic years, we were so happy then, weren't we? Well, we converted only three years ago. And our life changed so much for the better. What changed, exactly? Well, difficult to say what changed exactly... but we are definitely happier now than we were before, right? (Rodrigo, 32, 08.12.2017)

Pentecostals have a tradition of dramatic conversion experiences, and, at the same time, dramatic and radical changes in their lives, which are supposed to be evidence of the veracity of conversion. Therefore, it seems that some of the stories about the dark past might really be a bit exaggerated, just like the stories about the fantastic life after conversion, when everything literally changes for the better. I did have an impression that the only memories that one should share about the "previous" life are supposed to be bad, that they should show what a difficult and hopeless life they had before the conversion. It seems that the conversion experience is supposed to create (and it really does) a strong psychological bond among the "brethren," and between the pastor and individual members of "his herd" - these are actually the only people who are able to understand exactly what has happened, drawing on their own experiences. There is usually also a sense of close proximity with the pastor, who was often not only a witness, but even a direct cause of conversion - a conveyor of the message of God. Converting therefore also means submitting to the authority of the local pastor. However, sometimes the disciple outgrows the master, becoming even more active, spontaneous and involved. That is where an inverted spiritual dichotomy takes place between the missionary and the convert. And this is usually when a new church starts up, often preventing problems, conflicts, and personal tensions. Or

${ }^{34}$ P.L. Berger, T. Luckmann, The Social Construction of Reality, Harmondsworth 1984, p. 180. 
a new daughter-church is born, thus practically frictionlessly solving, by means of further Pentecostal expansion, any possible difficulties linked to handling "deviant," or "internal oppositional" behaviour of strong personalities appearing within the group. Júnior $(38,06.12 .2017)$ and Tobias $(46,09.12 .2017)$ recount their experiences of the above:

I simply understood that I must have been somehow chosen. It took me some time, but it was clear to everybody that I was somehow different, developing much faster than the rest of the group. You cannot really do anything about it - it is not you yourself, it is the Lord who does it. You cannot do much more than simply trust and believe that what He wants for you is good. The pastor himself told me to try my own congregation. And I did. I liked him a lot. I trusted him. So I decided to stay within his structure, but taking care of a completely different sector, which was much closer to me: in my own borough. People knew me there; they knew my history. I established myself quite quickly - first continuing to work professionally and preparing services twice a week. Then I succeeded in attracting enough people to be able to maintain myself and my family only on what they give to the church. I have been a pastor for almost ten years now. And I wouldn't have exchanged this job for anything... anything in the world. Really.

When I started "growing," it was quite a painful experience because I could see things that we, as a congregation, were not doing right... So I started criticizing here and there... the pastor was not really happy with that. He was not actually happy at all. I thought about it for a while, but before I made up my mind, he called me first and suggested that I should go my own way before I spoil the work of his life. I considered it a bit strong, you know... I was surprised, shocked a little. I felt rejected, sort of laid off. And I knew I was a worthy member of the group, I was the one who had really been doing things: healings, speaking in tongues, that kind of story... there are people who never manage to do anything. And I did. And then he treated me like that. I decided to back out. And I did. I set up my own church. It was difficult at first, as I had to learn all by myself. I should have stayed there for some more time, learned a bit more, and then left. But then, when he had already spoken to me like that, there was no choice. So I just left. And here I am. Quite happy with what I have been doing since.

In Pentecostal conversion there is no formal preparation, catechism, profession of faith. Conversion is a private, individual experience, which is possible due to the work of the Holy Spirit. It can be achieved in minutes. What is emphasized is always the experience - and the more "ecstatic" and "charismatic," the better. The results are "spiritual gifts," like glossolalia and healing. But there are some other, less popular gifts, which can still be bestowed, though: prophesy, discerning of spirits, working of miracles, interpretation of tongues... It is an extremely emotive religion. Full of wonders.

I chose to follow God under that big mangueira tree, over there. On that day, there was a meeting there, the pastor was preaching in the open air, I just stood by for a while to see, out of curiosity... I thought for a while those were some psychos - they cried, they prayed, they repented so loudly... and many of them singing at the same time. (Cristine, 27, 05.12.2017)

Pentecostal converts seem to be disciplined, conscious of their duties and obligations following conversion. They have a set of rules to obey and they try hard not to fail. This change of behaviour serves as a sign and evidence of more substantial, invisible change that has been sparked in their spiritual life as a consequence of conversion. The converts often explain this behaviour by their "functionality" and "usefulness," by the actual strength of their religion: 
Faith has to be effective, one has to feel the results, they need to be tangible. Religion must be put into practice. If faith does not work, you can easily abandon it. It is a useless burden - I was carrying such a useless burden for many decades. Not understanding anything. Going to church, participating, going out, living as before. It didn't change me; it didn't change my world. So why should I have stayed there? (Jaqueline, 35, 12.12.2017)

What seems to be interesting is that there appears in these talks another, apparently important, factor of conversions: the problem of guilt, repentance, and redemption. Pentecostals emphasize the joy of conversion, the power of the Gospel, the strength of faith, and the infinity of God's love and forgiveness - the divine power being so strong that one can leave it all in His hands, individually and collectively, freeing oneself from the troubles of everyday life, transforming one's life with no sense of guilt, with a total "carte blanche." The conversion manifests itself in the working of the Holy Spirit, not that of the individual, who, no matter how strong his or her needs or merits, might never experience the grace of "the outpouring." Therefore, expectations and "gradations" of membership are linked to the visibility and tangibility of the received gifts: some people fall to the ground, as if they had been struck by lightning; some enter into a kind of trance; some others keep kneeling for hours praying loudly with no need for rest. Afterwards, they say they are totally transformed, renewed. They just start a new life - here and now. Or, as someone put it: "you finally start being yourself." You only talk about your "previous, old" life in your public testimonies, comparing it, as I have already shown, in a clear, "black and white" way with the "new, blessed" life after conversion. And "infecting" others with your enthusiasm.

\section{Conclusions}

The relations between religion, society, and its culture have been and continue to be of interest to scholars, independent of the theoretical orientation they apply in their research. These theories encompass a wide spectrum, as was shown in the first part of the article, although not many universal theories have ever been applied or tested in Brazil and few of them are directly related to the Brazilian context, or based on research carried out in Brazil. Each theory separately seems to be insufficient as a sole interpretation of the popularity of Pentecostalism and the phenomenon of conversions in Brazil, as no single theory exhaustively explains this topic. There is always a need to complement any of the given theories and flexibly modify them for the Brazilian situation, where the strength and popularity of the Pentecostal option is to a great extent related not only to purely spiritual and individual factors, but also to key socio-cultural determinants. These determinants include: Christianity vs. local characteristics (Brazilian culture with African roots that puts experience before reflection, symbols before dogmas, speaking before writing, liberty of expression before any social censorship); the high supply of charismatic religious leaders (who catalyse such transformations, often provoking them); the unity of a given religious offer and both cultural demands and perspectives of improvement (if only subjective) 
of quality of life in a highly divided Brazilian society troubled by violence, through the direct intervention of supernatural powers and the feeling of safety, self-esteem and moral righteousness provided by precise rules to follow and the sure support of leaders and "brethren" in times of need.

Anyone with some knowledge of Brazilian reality is fully aware of its many different Pentecostal/Evangelical expressions and an almost continuous effervescence in this part of its religious market: "We meet with a very intense, spiritual and religious movement of revival [...] today much more than in the past." 35 But those who are familiar with Brazil also know only too well about its problems: enormous social discrepancies, problems in the health sector and education, corruption, and urban violence. All of these have definitely influenced the fertile background for the growing popularity of the Pentecostal movement, offering generous promises of rapid and radical changes in believers' lives through the activity of the Holy Spirit. Pentecostalism, without any doubts, provokes, inspires, and requires these changes in the life of the neophyte, who interprets them as the effects of being chosen by God, and being touched by his grace, which is an experience that psychologically culminates in new powers to resist temptations, transforming the life of the individual, who, even if humble, stops being regarded as "silent." Pentecostals become illuminated by the Holy Spirit, they prove to be equal to others, they are listened to when they appear with their conversion stories with the Bible in their hands, they are respected when they receive gifts (e.g. glossolalia). Pentecostalism definitely provides a setting where people are encouraged to talk about their spiritual life without any embarrassment, about their visions and dreams. In such a fellowship with others, through the conversion, the converts start sharing experiences, beliefs, but also problems. An emphasis on community and the strong position of the pastor show that individual conversion, in spite of being important, is not everything - it must be shared with others, with the congregation. People who have had a strong conversion experience and are "close to God" earn respect, substantially strengthening their social and symbolic capital. Therefore, conversion is something desirable; it seems to be the clue to understanding the popularity of Pentecostalism, being the moment or the process of spiritual experience that people long to go through, creating commitment, a driving force for life. Conversion is desired and expected to be an overwhelming experience, profoundly life-changing, and resulting in a surprising proselytizing zeal, bringing more people to churches. I still remember a young waiter in one of the restaurants, who, between advising on orders, managed to also tell me with a friendly smile that God loves me and has got plans for me at the Pentecostal church he has just started attending... and, of course, I went there, out of "scientific curiosity." But there are many people who will go there thinking that it cannot be any coincidence that "someone invites them like this, completely out of the blue, today..."

Although, as I showed in the second part of the article, the conversion - viewed usually as a sudden, sometimes dramatic individual experience - entails new norms, values, and identities, it is always situated within a given context: social, cultural, and

${ }_{35}$ C.R. Brandão, As muitas moradas, crenças e religiões no Brasil de hoje, [in:] Curso de verão, ano VII, J.O. Beozzo (ed.), São Paulo 1993 (Coleção teologia popular), pp. 77-106, p. 82. 
sometimes even political. This is particularly visible when Pentecostals talk about the current, difficult situation in their country, viewing it through the lens of their faith and the need to evangelize: only then, as they explain, is there some hope of changing it.

One of very important aspects of the popularity of the Pentecostal movement in Brazil is definitely its leadership: the power and the authority of pastors are perceived as positive and determining the course of their churches. The strong position of the pastor means that he can largely decide where the members of his congregation invest time, money and energy. It is the pastor who officially welcomes new members, who has the power to discipline, to guide, and to ask them to leave. In Brazil, there is a full acceptance of strong, authoritarian religious leaders with a patriarchal attitude, if there is full recognition of their "giftedness" and "exceptionality." The pastors are not necessarily educated, but they are all talented and enthusiastic speakers, aware of the needs of the community members, available and close to their "herd." But, in order to be successful, they must all have "a mandate" from the Holy Spirit, which is visible by means of the efficiency of prayers, healings, and gifts. Conflicts of leadership within a given church usually end up in a schism, which actually makes the movement itself grow even further, with new churches sprouting almost every day.

Taking everything into consideration, I confirm that Pentecostal conversion - a dramatic individual experience, changing the lives of the converts - is in itself an extremely attractive phenomenon that allures people to Pentecostalism, making many Brazilians simply want to live through the experience. However, Brazilian Pentecostal expansion is also closely linked with not only specific cultural demands on the part of Brazilians, but also with self-confident, strong charismatic Pentecostal leadership and important features of a highly-divided Brazilian society. In this society, the status of Pentecostal converts is often low, which emphasizes the role of social and communitarian support in their journey of (de/re)constructing their lives, families and identities.

\section{References}

Alvarsson J.-A., Siuda-Ambroziak R., Religiones e iglesias en la formación de una nueva América Latina a finales del siglo XX y principios del siglo XXI, [in:] América Latina del siglo XXI. Nuevas semblanzas, nuevas estructuras, nuevas identidades, A. Dembicz, A. Elbanowski (eds.), Warszawa 2013, pp. 353-410.

Amit V., Introduction: Constructing The Field, [in:] Constructing the Field. Ethnographic Fieldwork in the Contemporary World, V. Amit (ed.), London-New York 2000.

Anderson A.H., Spreading Fires: The Missionary Nature of Early Pentecostalism, London 2007.

Bateson G., A Systems Approach, "International Journal of Psychiatry" 1971, no. 9, pp. 242-244.

Beckford J., Teoria społeczna a religia, transl. M. Kunz, T. Kunz, Kraków 2006.

Berger P.L., Luckmann T., The Social Construction of Reality, Harmondsworth 1984.

Between Babel and Pentecost: Transnational Pentecostalism in Africa and Latin America, Corten A., Marshall-Fratani R. (eds.), London 2001.

Beyer P., Religia i globalizacja, transl. T. Kunz, Kraków 2005.

Bloch-Hoell N., The Pentecostal Movement, London 1964. 
Bourdieu P., Social Being, Time and a Sense of Existence, [in:] idem, Pascalian Meditations, Cambridge 2000.

Brandão C.R., As muitas moradas, crenças e religiões no Brasil de hoje, [in:] Curso de verão, ano VII, J.O. Beozzo (ed.), São Paulo 1993 (Coleção teologia popular), pp. 77-106.

Brusco E.E., The Reformation of Machismo. Evangelical Conversion and Gender in Colombia, Austin 1995.

Bryant M.D., Lamb C., Introduction. Conversion: Contours of Controversy and Commitment in a Plural World, [in:] Religious Conversion. Contemporary Practices and Controversies, M.D. Bryant, C. Lamb (eds.), London-New York 1999.

Calhoun C., The Social Theory and the Public Sphere, [in:] The Blackwell Companion to Social Theory, Turner B. (ed.), Oxford 1995, pp. 429-470.

Casanova J., Religie publiczne w nowoczesnym świecie, transl. T. Kunz, Kraków 2005.

Cox H., Fire from Heaven: The Rise of Pentecostal Spirituality and the Reshaping of Religion in the Twenty-First Century, Reading, MA 1995.

Cox H., The Secular City, London 1965.

Cucchiari S., "Adapted for Heaven”: Conversion and Culture in Western Sicily, “American Ethnologist" 1998, no. 15 (1), pp. 417-441.

Dayton D., Theological Roots Of Pentecostalism, Peabody, MA 2000.

Dionne E.J., Dilulio J., What's God Got To Do with the American Experiment?, Washington D.C. 2000.

Dobbelaere K., Sekularyzacja. Trzy poziomy analizy, trans. R. Babińska, Kraków 2008.

Hall D., Religious Attendance More Cost-Effective than Lipitor?, "Journal Of The American Board Of The Family Medicine" 2006, no. 19, pp. 130-139.

Hastrup K., Fieldwork among Friends: Ethnographic Exchange Within The Northern Civilization, [in:] Anthropology at Home, A. Jackson (ed.), London-New York 1987.

Heelas P., Introduction: On Differentiation and Dedifferentiation, [in:] Religion, Modernity and Postmodernity, P. Heelas, D. Martin, P. Morris (eds.), Oxford 1998.

Hefner R.W., Introduction, [in:] Conversion to Christianity, R.W. Hefner (ed.), Berkeley-Los Angeles-Oxford 1993.

Herzfeld M., Anthropology through the Looking Glass: Critical Ethnography in the Margins of Europe, Cambridge 1987.

Hill K.Q., Matsubayashi T., Church Engagement, Religious Values and Mass-Elite Policy Agenda Agreement in Local Communities, "American Journal of Political Science” 2008, vol. 52, no. 3, pp. 570-584.

Hollenweger W.J., The Black Roots of Pentecostalism, [in:] Pentecostals after a Century: Global Perspectives on a Movement in Transition, A. Anderson, W.J. Hollenweger (eds.), Sheffield 1999.

Jackson M., Minima Ethnografica, Chicago-London 1998.

Luckmann Th., Niewidzialna religia. Problem religii we współczesnym świecie, transl. L. Bluszcz, Kraków 2006.

Martin D., A General Theory of Secularization, Oxford 1978.

Martin D., Pentecostalism: The World Their Parish, Oxford-Malden, MA 2002.

Martin D., Tongues on Fire: The Explosion of Protestantism in Latin America, Oxford 1993.

Mueller P.S, Plevak D.J., Rummans T.A., Religious involvement, spirituality, and medicine: implications for clinical practice, "Mayo Clinic Proceedings" 2001, no. 76, pp. 1225-1235.

Norris P., Inglehart R., Sacrum i profanum. Religia i polityka na świecie, transl. R. Babińska, Kraków 2006.

Putnam R., Bowling Alone: The Collapse and Revival Of American Community, New York 2000.

Robeck C.M. Jr., The Azusa Street Mission and Revival: The Birth of the Global Pentecostal Movement, Nashville, TN 2006. 
Siuda-Ambroziak R., Brazylijski rynek religijny na początku XXI wieku (na podstawie danych ze spisu powszechnego IBGE z roku 2010), "Ameryka Łacińska” 2013, vol. XIX, no. 1 (79), pp. 99-106.

Siuda-Ambroziak R., As mudanças e transformações recentes do mercado religioso brasileiro, "Iberoamericana Quinqueeclesiensis" 2016, vol. XIV, pp. 15-23.

Siuda-Ambroziak R., Religia w Brazylii. Uwarunkowania społeczno-kulturowe, Kraków 2015.

Siuda-Ambroziak R., Religião e Estado no Brasil contemporâneo: os processos da "(neo)pentecostalização" da política brasileira, [in:] Religión y politica en América Latina, Krzywicka K., Siuda-Ambroziak R. (eds.), "Estudios Latinoamericanos de la UMCS” 2017, vol. V, pp. 109136.

Stoll D., Is Latin America Turning Protestant? The Politics of Evangelical Growth, Berkeley-Los Angeles 1990.

Stromberg P., Language and Self-Transformation. A Study of the Christian Conversion Narrative, Cambridge 1993. 